\title{
IDENTIFIKASI TELUR NEMATODA USUS SOIL TRANSMITTED HELMINTHS (STH) PADA KUKU JARI TANGAN PEKERJA TEMPAT PENITIPAN HEWAN METODE PENGAPUNGAN (FLOTASI) MENGGUNAKAN NaCl
}

\author{
Dwi Aprilia Anggraini, Norma Farizah Fahmi, Riyadatus Solihah, Yogi Abror \\ STIKes Ngudia Husada Madura \\ anggribecks87@gmail.com
}

\begin{abstract}
Abstrak
Penyakit cacingan merupakan penyakit endemik, bersifat kronik dan zoonosis. Soil Transmitted Helminths (STH) merupakan golongan cacing yang dapat menyebabkan infeksi kecacingan. Infeksi STH dapat ditularkan kepada manusia melalui berbagai cara, salah satunya adalah melalui kuku jari tangan yang kotor dan panjang sehingga dapat beresiko untuk kesehatan dan menyebabkan banyak mikroorganisme masuk. Penelitian ini bertujuan untuk mengidentifikasi telur nematoda usus STH pada kuku jari tangan dengan metode pengapungan. Jenis penelitian ini adalah analisis deskriptif dengan menggunakan metode pendekatan laboratorik, diambil 20 sampel secara purposive sampling di empat tempat penitipan hewan yang berbeda selanjutnya dilakukan identifikasi dengan metode pengapungan. Dari hasil identifikasi menunjukkan bahwa ditemukan adanya kontaminasi telur nematoda usus STH sebanyak $10 \%$ pada kuku jari tangan dengan metode pengapungan dan yang tidak terkontaminasi telur nematoda usus STH yaitu sebanyak 90\%,. Jenis telur cacing yang ditemukan adalah Trichuris sp dan Hookworm. Disarankan pekerja nantinya agar mampu menjaga kebersihan dari kuku jari tangan dan memakai alat pelindung diri (APD) sebelum memulai pekerjaan.
\end{abstract}

Kata Kunci: Kuku jari tangan yang kotor, Alat pelindung diri, Soil Transmitted Helminths (STH), Nematoda, Metode pengapungan

\section{Pendahuluan}

Observasi atau hasil pengamatan penyakit kecacingan di Indonesia masih banyak. Penyakit kecacingan merupakan masalah kesehatan, salah satu diantaranya adalah cacing perut yang ditularkan melalui tanah. Cacingan ini dapat mengakibatkan menurunnya kondisi kesehatan, gizi, 2 kecerdasan dan produktivitas penderitanya sehingga secara ekonomi banyak menyebabkan kerugian, karena menyebabkan kehilangan karbohidrat dan 
JURNAL ILMU KESEHATAN BHAKTI HUSADA:

HEALTH SCIENCES JoURNAL, Vol. 11 No. 02, DESEMBER 2020

DOI: $10.34305 / j i k b h . v 11 i 2.166$

protein serta kehilangan darah, sehingga menurunkan kualitas sumber daya manusia.

Prevalensi cacingan di Indonesia pada umumnya masih sangat tinggi, terutama pada golongan penduduk yang kurang mampu mempunyai risiko tinggi terjangkit penyakit ini (Surat Keputusan Menteri Kesehatan Nomor:

424/MENKES/SK/VI/2006, 2006).

Insiden atau kasus yang masih tinggi yakni cacing usus yang ditularkan melalui tanah (soil transmitted helminthiasis). Hal ini terjadi mengingat bahwa Indonesia adalah negara agraris dengan tingkat sosial ekonomi, pengetahuan, keadaan sanitasi lingkungan dan hygiene masyarakat masih rendah serta beriklim tropis sehingga sangat memungkinkan untuk terjadinya infeksi dan penularan cacing (Waqiah, 2010).

Jenis cacing yang hidup dan berkembang biak sebagai parasit di dalam tubuh manusia seperti Ascaris lumbricoides (cacing gelang) hidup dengan menghisap sari makanan, Trichuris trichiura (cacing cambuk) selain menghisap sari makanan juga menghisap darah, Ancylostoma duodenale dan Necator americanus (cacing tambang) hidup dengan menghisap darah saja, sehingga penderita cacingan akan kurus, dan kurang gizi, pada gilirannya

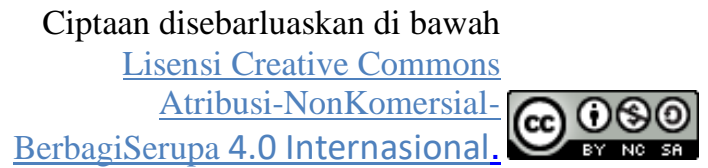

menjadi mudah lelah, malas belajar, daya tangkap menurun bahkan mengalami gangguan pencernaan (diare) yang berujung pada rendahnya mutu sumber daya manusia dan merosotnya produktivitas (Djamilah, 2003).

Penyakit atau infeksi zoonosis yang ditularkan secara alamiah di antara hewan vertebrata dan manusia. Peternakan di Indonesia rentan terhadap berbagai penyakit, termasuk zoonosis. Dengan demikian, zoonosis merupakan ancaman baru bagi kesehatan manusia. Zoonosis dapat ditularkan dari hewan ke manusia melalui beberapa cara, yaitu kontak langsung dengan hewan pengidap zoonosis dan kontak tidak langsung melalui vektor atau mengonsumsi pangan yang berasal dari ternak sakit, atau melalui aerosol di udara ketika seseorang berada pada lingkungan yang tercemar (Suharsono, 2002). Cacingan biasanya disebabkan karena larva yang menembus kulit saat berjalan di tanah tanpa menggunakan alas kaki. Kontaminasi terjadi melalui kotoran manusia yang mengandung larva cacing dan kemudian bercampur dengan tanah. Setelah terinfeksi, orang biasanya tidak mengalami gejala. Penyakit cacingan ini juga ditularkan melalui tangan yang kotor, kuku panjang dan kotor menyebabkan telur cacing 
JURNAL ILMU KESEHATAN BHAKTI HUSADA:

HEALTH SCIENCES JoURNAL, Vol. 11 No. 02, DESEMBER 2020

DOI: $10.34305 / j i k b h . v 11 i 2.166$

terselip. Salah satu penyebab tersebarnya telur cacing adalah kebersihan 3 perorangan yang masih buruk, termasuk didalamnya tidak mencuci tangan sebelum makan dan setelah buang air besar, serta mandi yang tidak dua kali sehari atau tidak menggunakan sabun dan air bersih.

Usaha pencegahan penyakit cacingan antara lain: menjaga kebersihan badan, kebersihan lingkungan dengan baik, makanan dan minuman yang baik dan bersih, memakai alas kaki, membuang air besar di jamban (kakus), memelihara kebersihan diri dengan baik seperti memotong kuku dan mencuci tangan sebelum makan. Kebersihan perorangan penting untuk pencegahan.

Pengertian hygiene berdasarkan Undang-Undang Republik Indonesia No 2 Tahun 1966 (1996), adalah kesehatan masyarakat yang khusus meliputi segala usaha untuk melindungi, memelihara, dan mempertinggi derajat kesehatan badan dan jiwa baik untuk umum maupun untuk perorangan dengan tujuan memberikan dasar-dasar kelanjutan hidup.

Penelitian tentang kebersihan kuku yang diabaikan menjadi penyebab terjadinya infeksi cacingan sebanyak $89.5 \%$ dikarenakan dibawah kuku yang panjang dan kotor terdapat banyak bakteri dan bibit

\section{Ciptaan disebarluaskan di bawah \\ Lisensi Creative Commons \\ Atribusi-NonKomersial- \\ BerbagiSerupa 4.0 Internasional.}

penyakit yang menyebabkan penyebaran infeksi termasuk cacing. Kuku harus dipotong pendek dan dijaga kebersihannya dengan menggunakan pemotong kuku atau gunting tajam, jika ada jaringan yang kering di sekitar kuku maka dioleskan lotion atau minyak mineral, serta kuku direndam jika tebal dan kasar. Telur cacing sering kali terselip pada kuku yang kotor. Kondisi ini sering terjadi pada anak yang sering bermain di tanah serta pada orang dewasa yang bekerja di kebun atau di sawah. Gejala yang seringkali tampak pada infeksi ini adalah kerusakan pada kuku, diantaranya kuku menjadi lebih tebal dan nampak dari dasar perlekatannya atau onycholysis, pecah-pecah, tidak rata dan tidak mengkilap lagi, serta perubahan warna lempeng kuku menjadi putih, kuning, coklat, hingga hitam (Setianingsih et al., 2015).

Hasil penelitian terdahulu oleh Desi Erni Dewi Pulungan tentang Hubungan Pemakaian Alat Pelindung Diri dengan Infeksi Cacing pada Pekerja Kebersihan di Kota Rantau, dari hasil penelitiannya diperoleh pekerja yang memakai alat pelindung diri secara lengkap hanya 30,4\% dan selebihnya $69,6 \%$ yang tidak memakai alat pelindung diri secara lengkap. 80,4\% pekerja kebersihan tersebut positif terinfeksi cacing, dan tidak terinfeksi cacing 
JURNAL ILMU KESEHATAN BHAKTI HUSADA:

HEALTH SCIENCES JoURNAL, Vol. 11 No. 02, DESEMBER 2020

DOI: $10.34305 / j i k b h . v 11 \mathrm{i} 2.166$

sebesar 19,6\%. Dengan metode eksak fisher dibuktikan secara statistik adanya hubungan yang bermakna antara tindakan pemakaian alat pelindung diri dengan infeksi cacing pada pekerja kebersihan di kota Rantau Prapat Tahun 2002, hal ini sangat beralasan karena $69,6 \%$ dari pekerjaan tersebut tidak menggunakan alat pelindung diri secara lengkap (Lamara, 2013).

Tempat penitipan hewan ini adalah sebagai tempat penitipan sementara hewan peliharaan yang ditinggalkan pemilik karena keperluan mendesak dan membutuhkan waktu lebih dari 1 hari. Biasanya hewan peliharaan dititipkan karena di rumah pemilik tidak ada yang bisa merawat anjing atau kucing. Pada area ini hewan peliharaan di rawat oleh kennel girl/ kennel boy (pegawai yang khusus menangani berbagai kebutuhan hewan peliharaan dan menjaga kebersihan kandang). Selain itu terdapat grooming area berfungsi sebagai tempat untuk memberikan pelayanan berupa jasa perawatan kuku, bulu, pembasmian kutu, dan jamur pada hewan peliharaan. Grooming area juga memberikan jasa pelayanan pemijatan sederhana pada hewan peliharaan. Pemijatan ini memberikan efek untuk kelancaran peredaran darah pada hewan peliharaan. Pada tempat penitipan

\section{Ciptaan disebarluaskan di bawah \\ Lisensi Creative Commons \\ Atribusi-NonKomersial- \\ BerbagiSerupa 4.0 Internasional.}

hewan juga terdapat fasilitas klinik dilengkapi dengan dokter hewan dan paramedik (Puspita, 2013).

Masalah kebersihan seringkali muncul pada setiap fasilitas khusus hewan. Perilaku hewan tidak mudah diatur untuk menjaga kebersihan. Oleh karena itu, tempat pelayanan kesehatan hewan harus terbebas dari berbagai hal yang berpotensi dapat memunculkan ancaman penyakit atau memperburuk kondisi kesehatan hewan. Di samping itu, pelayanan kesehatan hewan perlu berlangsung dalam suasana yang menyegarkan atau suasana yang nyaman dan dapat menenangkan. Suasana seperti itu dibutuhkan mengingat para pemilik hewan peliharaan datang ke sebuah klinik hewan, cenderung dalam kondisi perasaan sedih, cemas dan juga tegang karena memikirkan kondisi kesehatan hewan peliharaannya. Untuk itu maka suasana ruang atau tempat bagi mereka memerlukan dukungan elemen-elemen yang bersifat segar atau fresh seperti warna yang lembut, sejuk, serta suasana ruangan yang bersih (Akmalia et al., 2017).

Dari pengamatan penulis ada hal yang perlu menjadi perhatian dalam petugas tempat penitipan hewan yaitu alat pelindung diri atau APD baik berupa sarung tangan, topi, sepatu masih belum dimiliki. 
JURNAL ILMU KESEHATAN BHAKTI HUSADA:

HEALTH SCIENCES JoURNAL, Vol. 11 No. 02, DESEMBER 2020

DOI: $10.34305 / j i k b h . v 11 i 2.166$
Ciptaan disebarluaskan di bawah

Lisensi Creative Commons

Atribusi-NonKomersial-

BerbagiSerupa 4.0 Internasional.
Pada hal ini sangat penting dalam melindungi diri dari bahan infeksius dan bahan lain yang dapat mencelakakan. Hal tersebut dikarenakan tugas dari petugas kebersihan kandang/ kennel girl/ kennel boy yaitu mengawasi keadaan hewan (memotong kuku, menyisir rambut, memotong kuku, membersihkan mata, telinga, serta memandikan) melaporkan gangguan kesehatan maupun perilaku hewan kepada supervisor, melakukan perawatan dasar pada hewan (memandikan dan merawat kebersihan hewan). Petugas Perawatan Kandang Bertanggung jawab untuk menjaga kebersihan sanitasi daerah tinggal hewan penampungan secara keseluruhan, memastikan ada air segar harus tersedia dan mudah diakses oleh setiap hewan setiap saat, melakukan pengamatan yang cermat terhadap binatang di kandang dan taman sepanjang hari, untuk melihat bahwa hewan aman, sehat, dan nyaman, memastikan setiap hewan harus memiliki akses ke tempat tidur bersih dan kering, mengoperasikan/ mengontrol alat cuci kain dan wadah makan (Brawijaya, 2012).

Diagnosis cacingan dilakukan melalui identifikasi telur cacing pada pemeriksaan feses penderita. Pemeriksaan ini merupakan jenis pemeriksaan gold standard. Akan tetapi, berdasarkan cara penularan penyakit, maka pemeriksaan kuku pun dapat dilakukan untuk mendeteksi kemungkinan terjadinya penyakit kecacingan pada seseorang. Pada pemeriksaan telur cacing, terdiri dari dua jenis pemeriksaan yaitu; makroskopis dan mikroskopis. Tujuannya adalah untuk memeriksa parasit dan telur cacing. Pemeriksaan kualitatif dapat dilakukan dengan berbagai cara seperti; pemeriksaan secara natif (direct slide), pemeriksaan metode apung, modifikasi merthiolat iodine formaldehyde, metode selotip, dan metode sedimentasi (Rahmadhini \& Mutiara, 2015).

Metode flotasi (pengapungan) adalah metode yang menggunakan larutan $\mathrm{NaCl}$ jenuh yang didasarkan atas berat jenis telur sehingga akan mengapung ke permukaan tabung dan ditutup dengan cover gelas sehingga telur cacing naik ke permukaan larutan. Cover gelas tersebut dipindahkan ke objek glass yang bersih dan kering di bawah mikroskop. Pemeriksaan telur cacing (kualitatif) dapat menggunakan metoda natif, sedimen dan pengapungan. Zat pengapung dapat digunakan antara lain : gula jenuh dan garam jenuh. Fungsi zat pengapung untuk mengapungkan telur cacing, karena berat jenis (BJ) cairan lebih 
JURNAL ILMU KESEHATAN BHAKTI HUSADA:

HEALTH SCIENCES JoURNAL, Vol. 11 No. 02, DESEMBER 2020

DOI: $10.34305 / j i k b h . v 11 i 2.166$

tinggi dari BJ telur cacing. Pemeriksaan telur cacing (metoda kuantitatif) untuk menghitung telur cacing per gram feses (ttgt) dilakukan dengan metoda Stoll dan Metoda Mc. Master atau modifikasi Mc Master. Masing-masing cara pemeriksaan feses tersebut diatas memiliki kelebihan dan kekurangan, sehingga pada penggunaannya disesuaikan dengan tujuannya. Pemeriksaan dengan menggunakan metode ini dimaksudkan untuk mengidentifikasi tinja yang mempunyai sedikit telur. Cara identifikasinya yaitu dengan membedakan berat jenis telur dengan kotoran pada tinja. Pada dasarnya penggunaan $\mathrm{NaCl}$ jenuh (33 $\%)$ dimaksudkan agar telur-telur cacing dapat terapung ke permukaan larutan karena berat jenis telur lebih ringan dari kotoran yang lainnya. Tujuan dari metode apung tanpa disentrifugasi adalah mengetahui adanya telur cacing parasit usus Nematoda, Schistosoma, Dibothriocep halus, telur yang berpori-pori dari famili Tainidae, telur-telur Acanthocephala ataupun telur Ascaris yang infertil untuk infeksi ringan. Kelebihan dari metode apung tanpa disentrifugasi adalah dapat digunakan untuk infeksi ringan dan berat, telur dapat terlihat jelas (Aryawan, 2019).

Sesuai dengan latar belakang diatas penelitian ini bertujuan untuk menjelaskan

\section{Ciptaan disebarluaskan di bawah \\ Lisensi Creative Commons \\ Atribusi-NonKomersial- \\ BerbagiSerupa 4.0 Internasional}

infeksi nematoda usus pada kuku jari tangan pada tempat penitipan hewan sebagai pencegahan kejadian zoonosis dengan menggunakan metode apung.

\section{Bahan dan Metode}

\section{Bahan}

Rancangan penelitian menggunakan metode analisis observasional deskriptif (Survey deskriptif) dengan pendekatan laboratorik. Desain penelitian dengan melihat gambaran jenis telur cacing pada spesimen kuku jari tangan para pekerja penitipan hewan menggunakan menggunakan larutan $\mathrm{NaCl}$ jenuh.

\section{Teknik dan Rancangan Penelitian}

Penggunaan jenis purposive sampling pada penelitian ini yaitu teknik pengambilan sampel yang dilakukan secara sengaja sesuai kriteria atau tujuan yang telah ditetapkan oleh peneliti. Sampel yang digunakan adalah kuku jari tangan groommer, kennel boy, paramedis, dan dokter hewan dari tempat penitipan hewan yang dilengkapi dengan fasilitas klinik dengan jumlah sampel 20. larutan $\mathrm{NaCl}$ jenuh, dan aquades. Instrumentasi yang akan digunakan diantaranya: gelas, cutter, batang pengaduk, pipet tetes, sentrifugasi, tabung sentrifus, tabung reaksi, rak tabung, object glass, cover glass, dan mikroskop. 
Waktu penelitian ini dilaksanakan pada bulan Maret - Juli 2019. Tempat penelitian dilaksanakan di Laboratorium Parasitologi Stikes Ngudia Husada Madura,
Jalan J1 RE. Martadinata No.45, Wr 06, Mlajah, Kec. Bangkalan, Kabupaten Bangkalan, Jawa Timur 69116.

\section{Hasil}

Tabel 1 Data hasil pemeriksaan kuku jari tangan yang telah direndam dengan $\mathrm{NaCl}$ jenuh:

\begin{tabular}{|c|c|c|c|}
\hline No & Sampel kuku jari tangan & Hasil pemeriksaan & Spesies telur nematoda usus \\
\hline 1 & $\begin{array}{l}\text { Sampel satu } \\
\text { (Tempat penitipan hewan satu) }\end{array}$ & Negatif & Negatif \\
\hline 2 & $\begin{array}{l}\text { Sampel dua } \\
\text { (Tempat penitipan hewan satu) }\end{array}$ & Negatif & Negatif \\
\hline 3 & $\begin{array}{l}\text { Sampel tiga } \\
\text { (Tempat penitipan hewan satu) }\end{array}$ & Negatif & Negatif \\
\hline 4 & $\begin{array}{l}\text { Sampel empat } \\
\text { (Tempat penitipan hewan satu) }\end{array}$ & Positif & Trichuris sp \\
\hline 5 & $\begin{array}{l}\text { Sampel lima } \\
\text { (Tempat penitipan hewan satu) }\end{array}$ & Negatif & Negatif \\
\hline 6 & $\begin{array}{l}\text { Sampel enam } \\
\text { (Tempat penitipan hewan dua) }\end{array}$ & Negatif & Negatif \\
\hline 7 & $\begin{array}{l}\text { Sampel tujuh } \\
\text { (Tempat penitipan hewan dua) }\end{array}$ & Negatif & Negatif \\
\hline 8 & $\begin{array}{l}\text { Sampel delapan } \\
\text { (Tempat penitipan hewan dua) }\end{array}$ & Negatif & Negatif \\
\hline 9 & $\begin{array}{l}\text { Sampel sembilan } \\
\text { (Tempat penitipan hewan dua) }\end{array}$ & Negatif & Negatif \\
\hline 10 & $\begin{array}{l}\text { Sampel sepuluh } \\
\text { (Tempat penitipan hewan dua) }\end{array}$ & Negatif & Negatif \\
\hline 11 & $\begin{array}{l}\text { Sampel sebelas } \\
\text { (Tempat penitipan hewan tiga) }\end{array}$ & Positif & Hookworm \\
\hline 12 & $\begin{array}{l}\text { Sampel dua belas } \\
\text { (Tempat penitipan hewan tiga) }\end{array}$ & Negatif & Negatif \\
\hline 13 & $\begin{array}{l}\text { Sampel tiga belas } \\
\text { (Tempat penitipan hewan tiga) }\end{array}$ & Negatif & Negatif \\
\hline 14 & $\begin{array}{l}\text { Sampel empat belas } \\
\text { (Tempat penitipan hewan tiga) }\end{array}$ & Negatif & Negatif \\
\hline 15 & $\begin{array}{l}\text { Sampel lima belas } \\
\text { (Tempat penitipan hewan tiga) }\end{array}$ & Negatif & Negatif \\
\hline 16 & $\begin{array}{l}\text { Sampel enam belas } \\
\text { (Tempat penitipan hewan empat) }\end{array}$ & Negatif & Negatif \\
\hline 17 & $\begin{array}{l}\text { Sampel tujuh belas } \\
\text { (Tempat penitipan hewan empat) }\end{array}$ & Negatif & Negatif \\
\hline 18 & $\begin{array}{l}\text { Sampel delapan belas } \\
\text { (Tempat penitipan hewan empat) }\end{array}$ & Negatif & Negatif \\
\hline 19 & $\begin{array}{l}\text { Sampel sembilan belas } \\
\text { (Tempat penitipan hewan empat) }\end{array}$ & Negatif & Negatif \\
\hline
\end{tabular}


JURNAL ILMU KESEHATAN BHAKTI HUSADA:

HEALTH SCIENCES JoURNAL, Vol. 11 No. 02, DESEMBER 2020

DOI: $10.34305 /$ jikbh.v11i2.166
Ciptaan disebarluaskan di bawah

Lisensi Creative Commons

Atribusi-NonKomersial-

BerbagiSerupa 4.0 Internasional.

\section{@®๑}

20 Sampel dua puluh

(Tempat penitipan hewan empat)

Negatif

Negatif

Berdasarkan data tabel 1 pemeriksaan kuku jari tangan menggunakan metode pengapungan dengan metode $\mathrm{NaCl}$ jenuh yaitu didapatkan hasil positif ditemukan adanya telur nematoda usus pada sampel empat tempat penitipan hewan pertama.

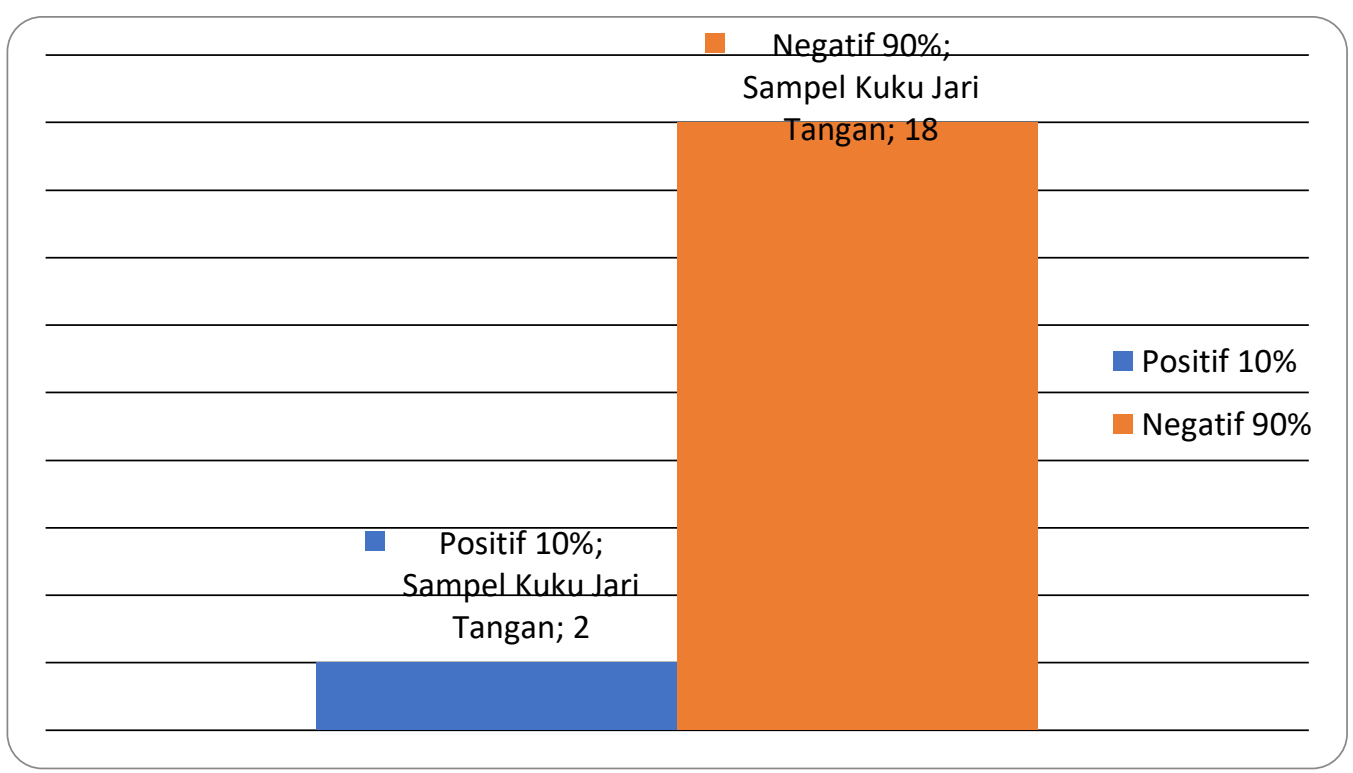

Gambar 1 Perbandingan prosentase jumlah telur nematoda usus pada kuku jari tangan pekerja tempat penitipan hewan

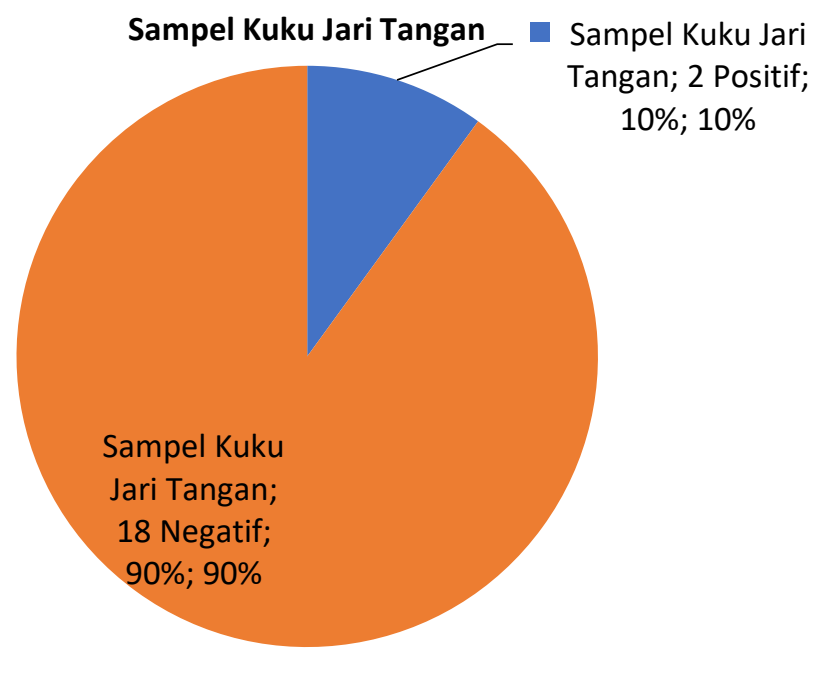


JURNAL ILMU KESEHATAN BHAKTI HUSADA:

HEALTH SCIENCES JOURNAL, VoL. 11 No. 02, DESEMBER 2020

DOI: $10.34305 / j i k b h . v 11 i 2.166$
Ciptaan disebarluaskan di bawah

Lisensi Creative Commons

Atribusi-NonKomersial-

BerbagiSerupa 4.0 Internasional.

Gambar 2 Data hasil pemeriksaan kuku jari tangan yang telah direndam dengan $\mathrm{NaCl}$ jenuh

Berdasarkan hasil pada Gambar 1 dan Gambar 2 menunjukkan bahwa ditemukan adanya kontaminasi telur nematoda usus STH sebanyak 5\% pada kuku jari tangan pada sampel nomor empat di tempat penitipan hewan yang pertama sedangkan pada sampel lainnya dapat dikatakan negatif.
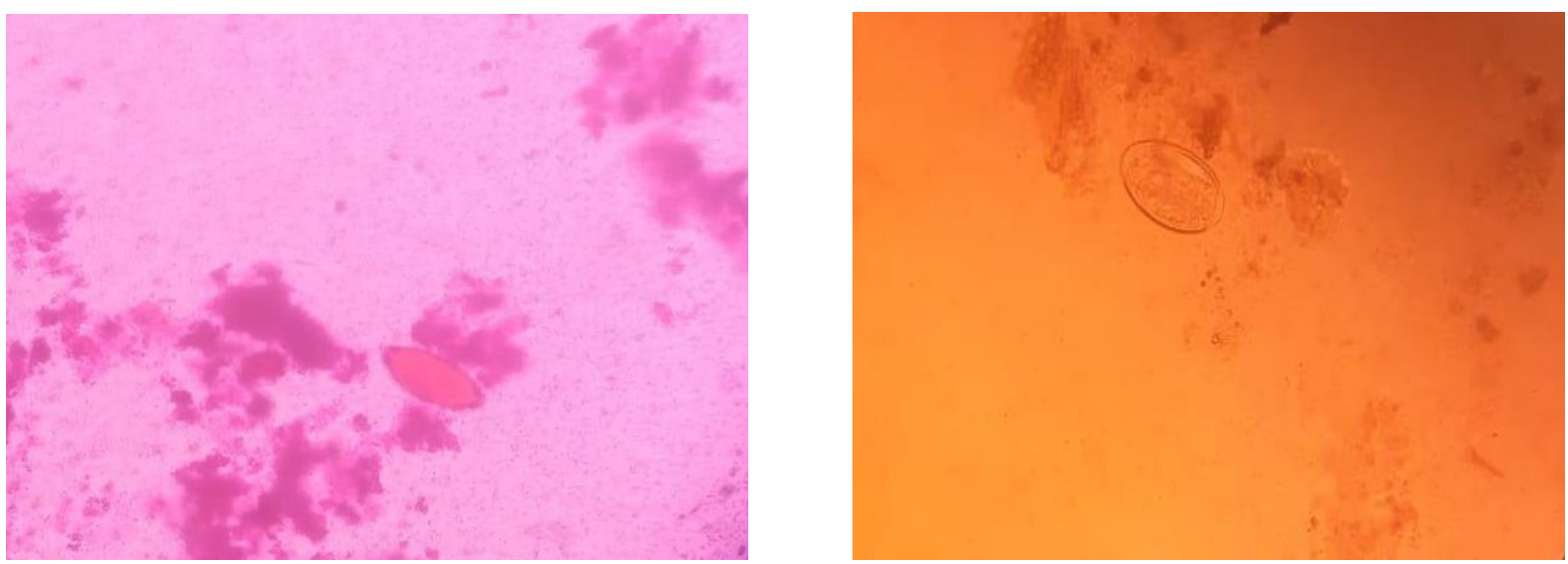

Gambar 3 telur cacing Trichuris sp (kiri) sampel tiga kuku jari tangan tempat penitipan hewan satu dan telur cacing tambang Hookworm (kanan) sampel sebelas kuku jari tangan tempat penitipan hewan tiga

Sesuai dengan gambar di atas (gambar 3 kanan) telur cacing Hookworm (Ancylostoma duodenale dan Necator americanus) karena telur tumbuh dan berkembang di tanah berpasir yang lembab dalam waktu cepat, yaitu telur berkembang menjadi embrio dalam waktu 24-48 jam pada suhu 23 sampai $30^{\circ} \mathrm{C}$ (Chiodini et al., 2001). Morfologi Mulut (buccal cavity) panjang dan sempit. Esofagus berbentuk seperti tabung (bulbus oeshophagus) terletak di sepertiga anterior. Larva rhabditiform merupakan larva yang keluar dari telur dan berkembang di dalam tinja atau tanah. Larva ini akan mengalami pergantian kulit sebanyak dua kali dalam 510 hari. Selanjutnya larva ini akan berkemban menjadi larva filariform. Larva ini inefektif dan dapat tetap hidup di lingkungan luar selama 7-8 minggu pada kondisi lingkungan yang optimal (Pusarawati et al., 2013). Bentukan (morfologi) telur dari nematoda ini sangat khas, terlihat mirip tempayan kayu atau 
JURNAL ILMU KESEHATAN BHAKTI HUSADA:

HEALTH SCIENCES JoURNAL, Vol. 11 No. 02, DESEMBER 2020

DOI: $10.34305 / j i k b h . v 11 i 2.166$

mirip biji melon (gambar 3 kiri). Berwarna coklat, mempunyai dua kutub yang jernih menonjol dan berukuran sekitar 50 x 25 mikron. Telurtelur menetas di usus kecil dan akhirnya melekat pada mukosa usus besar. Telur dikeluarkan dalam stadium belum membelah dan membutuhkan 10 sampai 14 hari untuk menjadi matang pada tanah yang lembab (Soedarto Soekirman, 1991).

\section{Pembahasan}

Kontaminasi Cacing Pada Kuku Pekerja Tempat Penitipan Hewan

Setelah dilakukan penelitian di Laboratorium Parasitologi Stikes Ngudia Husada Madura didapatkan hasil 2 sampel yang diperiksa terkontaminasi telur cacing nematoda usus STH. Spesies telur cacing yang ditemukan dari pemeriksaan ini adalah Trichuris sp dan Hookworm.

Hasil dari penelitian pendekatan laboratorik ini ditemukan telur Trichuris $s p$ dengan ciri morfologi telurnya berbentuk tong dengan tombol yang transparan. Berukuran panjang 50x54 mikron dan lebar 22x23 mikron. Kerusakan pada mukosa dan respon alergi dari hospes, merupakan faktor utama untuk setiap kelainan patologi yang berkaitan dengan infeksi ini dan berhubungan erat dengan jumlah cacing,

\section{Ciptaan disebarluaskan di bawah \\ Lisensi Creative Commons \\ Atribusi-NonKomersial- \\ BerbagiSerupa 4.0 Internasional.}

lamanya infeksi, dan umur serta status kesehatan umum dari hospes. Meskipun cacing menyusup kedalam epitel sekum, kerusakan akibat proses ini yaitu timbul disentri, pada keadaan ini mukosa terjadi edema dan rapuh, dapat disertai kejang perut, tenesmus rectum yang hebat, dan prolaps rectum (Padmasutra et al., 1996).

Penularan pada manusia dapat terjadi biasanya berhubungan dengan masalah sanitasi lingkungan yaitu masyarakat yang hidup di lingkungan kumuh atau pedesaan, dengan demikian penyebaran cacing berkaitan dengan sosialekonomi masyarakat di samping keadaan iklim dan geografis dari suatu daerah. Berdasarkan penelitian yang dilakukan menunjukkan bahwa, Trichuris vulpis dari anjing menginfeksi manusia mengakibatkan ulser duodenum dan diare kronis (Dunn et al., 2002).

Selain telur Trichuris sp ditemukan juga telur Hookworm yang telah berisi embrio. Spesies dari Hookworm ada 2 yaitu Necator americanus dan Ancylostoma duodenale. Penyakit oleh Necator americanus disebut necatoriasis dan oleh Ancylostoma duodenale disebut ancylostomiasis. Penyakit cacing tambang (hookworm) merupakan suatu infeksi kronis. Serangan cacing dewasa dapat 
JURNAL ILMU KESEHATAN BHAKTI HUSADA:

HEALTH SCIENCES JoURNAL, Vol. 11 No. 02, DESEMBER 2020

DOI: $10.34305 / j i k b h . v 11 i 2.166$

menyebabkan anemia yang disebabkan kehilangan darah secara terus menerus. Satu ekor cacing dapat menghisap darah setiap hari $0,1-1,4 \mathrm{~cm}^{3}$, berarti penderita yang mengandung 500 ekor cacing akan kehilangan $50-500 \mathrm{~cm}^{3}$ setiap harinya.

Analisis Lingkungan, Perilaku, dan Hospes Terkait Keberadaan Cacing pada kuku jari tangan

Menurut RISKESDAS (2008), prevalensi cacingan di Indonesia masih relatif tinggi yaitu sebesar $32,6 \%$ dan didominasi oleh Ascaris lumbricoides, Trichuris trichiura, Ancylostoma duodenale dan Necator americanus. Hal ini sesuai dengan pengamatan dilapangan bahwa personal hygiene para pekerja memiliki kecenderungan mengalami infeksi cacingan, karena sebagian besar responden yang mengalami infeksi cacingan memiliki personal hygiene yang tidak baik adalah salah satu faktor yang mempengaruhi prevalensi cacingan. Selain itu, kurangnya pengetahuan tentang pemahaman standar prosedur kerja yang baik dan tidak digunakannya alat-alat pelindung diri (APD) selama bekerja. Banyak spesies cacing (helminth) menimbulkan investasi pada manusia.

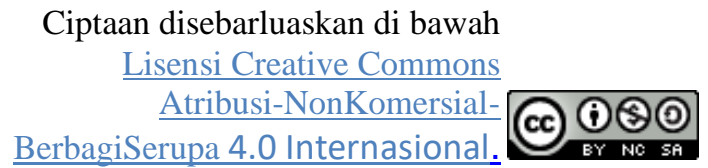

Cacing ini memiliki gigi kecil yang digunakan untuk melukai dinding usus untuk menghisap darah sehingga penderita cacing ini akan mengalami pendarahan akibat peradangan dan anemia. Telur yang keluar 18 melalui feses akan menetas pada tempat-tempat yang becek karena pada tempat kering telur akan mati. Telur yang menetas akan menjadi larva yang masuk ke dalam tubuh manusia melalui makanan dan minuman yang terkontaminasi. Larva yang menembus kulit akan dibawa oleh aliran darah menuju paru-paru, kemudian masuk ke dalam alveolus, trakea, esophagus, kemudian masuk ke lampoon dan menuju ke usus menjadi cacing dewasa (Onggowaluyo, 2001).

Kotoran hewan pada saat di tempat penitipan didapat dari hasil memandikan, memotong bulu hewan, memberi makan ataupun pemeriksaan hewan secara berkala lain. Pada kuku yang panjang dan tidak terawat pada para pekerja akan menjadi tempat melekatnya berbagai kotoran yang mengandung berbagai bahan dan mikroorganisme diantaranya bakteri, virus, jamur dan parasit (telur cacing). Penularan cacingan diantaranya melalui tangan yang kotor. Kuku jari tangan yang kotor, panjang dan tidak pernah dipotong pendek yang kemungkinan terselip telur cacing akan 
JURNAL ILMU KESEHATAN BHAKTI HUSADA:

HEALTH SCIENCES JoURNAL, Vol. 11 No. 02, DESEMBER 2020

DOI: $10.34305 / j i k b h . v 11 i 2.166$

tertelan ketika makan. Hal ini diperparah lagi apabila tidak terbiasa mencuci tangan memakai sabun sebelum makan.

Pemotongan kuku jari tangan dan kaki yang kurang tepat sangat erat kaitannya dengan aspek hygiene. Apabila kuku dalam keadaan panjang tidak bersih maka kotoran-kotoran yang terdapat di tangan disertai kuku yang panjang dan kotor bila tidak dicuci sebelum mengkonsumsi makanan menyebabkan masuknya telur cacing ataupun larva masuk kedalam tubuh.

Infeksi Soil Transmitted Helminth dapat menjangkit ke semua umur dari balita hingga orang dewasa. Infeksi kecacingan ini dapat terjadi secara individu ataupun kelompok seperti keluarga. Prevalensi dan intensitas dari golongan Soil Transmitted Helmith (STH) bervariasi di setiap umur dan jenis kelamin, jadi infeksi golongan Soil Transmitted Helmith (STH) bisa terjadi pada semua kalangan masyarakat (Subahar et al., 2017).

Banyak faktor yang mempengaruhi terjadinya cacingan, diantaranya yaitu iklim yang merupakan faktor yang utama dari infeksi cacing, kelembaban dan suhu juga mempengaruhi perkembangbiakan telur dan larva cacing nematoda usus golongan Soil Transmitted Heminth (STH), tanah yang lembab dan tidak terpapar oleh sinar matahari biasanya tempatnya paling cocok untuk perkembang telur dan larva cacing, maka dari itu kesadaran akan pentingnya pola hidup bersih dan sehat para pekerja batubata perlu ditingkatkan, salah satunya dengan mencuci tangan yang baik dan benar sebelum makan, dan sebaiknya menggunakan air mengalir, menggunakan alas kaki saat bekerja, beberapa hal tersebut dapat diterapkan oleh pekerja untuk meminimalisir terjadinya infeksi kecacingan bagi pekerja.

Penelitian yang dilakukan kali ini dapat memberikan contoh yang baik bagi bidang kesehatan bagaimana cara menurunkan resiko orang yang tidak memakai alas kaki atau mencuci tangan yang kurang baik, agar tidak terjadi infeksi cacingan yang khususnya kelas nematoda usus golongan Soil Transmitted Helminth (STH), didapatkan hasil dari jawaban responden terhadap kuesioner bahwa, mayoritas pekerja telah sadar akan pentingnya menjaga kebersihan diri dengan cukup baik, bekerja sendiri telah memiliki jamban sehat di rumahnya masing-masing, mencuci tangan dengan baik seperti dengan air mengalir dan sabun, cara-cara tersebut sangat baik untuk pencegahan terjadinya infeksi cacingan bagi pekerja 
JURNAL ILMU KESEHATAN BHAKTI HUSADA:

HEALTH SCIENCES JoURNAL, Vol. 11 No. 02, DESEMBER 2020

DOI: $10.34305 / j i k b h . v 11 i 2.166$

\section{Pencegahan Kontaminasi}

Infeksi STH yang ditularkan melalui tanah yaitu kebersihan kuku karena kuku yang panjang dapat memerangkap kotoran di dalamnya, kotoran yang berupa tanah dapat mengandung larva cacing yang infektif dan dapat menginfeksi. Perilaku yang tidak bersih yaitu menyebabkan infeksi terus berlanjut dari proses tertelannya telur atau larva karena kebiasaan kurang teratur mencuci tangan. Namun pendapat berbeda dalam penelitian yang dilakukan Sofiana (2010), memotong kuku seminggu sekali tidak memiliki hubungan yang bermakna dengan kejadian STH.

Pada dasarnya perilaku merupakan suatu tindakan dari individu untuk melakukan sesuatu berdasarkan stimulus atau rangsangan dari luar. Perilaku akan dipengaruhi berbagai faktor baik dari segi sosial maupun budaya yang tumbuh menjadi kebiasaan baik maupun buruk (Notoatmodjo, 2010). Perilaku yang berhubungan dengan kejadian STH diantaranya adalah kebiasaan cuci tangan pakai sabun cuci tangan merupakan salah satu langkah awal yang dapat dilakukan untuk mencegah terjadinya penularan berbagai macam penyakit. Tangan merupakan sarana yang baik untuk penularan penyakit, karena sebagian besar aktivitas dilakukan dengan menggunakan tangan, sehingga menjaga kebersihan tangan sangat perlu dilakukan. Penelitian yang dilakukan Jejaw et al (2014), bahwa mencuci tangan sebelum makan memiliki hubungan yang erat dengan kejadian STH di Ethiopia. Namun penelitian yang dilakukan oleh Sofiana (2010), menunjukan hal yang berbeda dimana perilaku mencuci tangan pakai sabun tidak menunjukkan hubungan yang bermakna dengan infeksi STH yang ditularkan melalui tanah.

\section{Pengobatan}

Beberapa pengobatan dilakukan untuk kecacingan pirantel pamoat, befenium hidroksinafloat, levamisol, mebendazole, dan oksantel pamoat memberikan hasil cukup baik, apabila mana digunakan beberapa hari berturut-turut (Gandahusada et al., 2004). Pencegahanya dapat dilakukan dengan menjaga kesehatan lingkungan, menggunakan alat pelindung ke tempat yang lembab dan temperatur yang merupakan habitat dari cacing ini. Memperhatikan tanah dan temperatur serta sinar matahari pada lingkungan yang dapat mengganggu perkembangan telur cacing. 
JURNAL ILMU KESEHATAN BHAKTI HUSADA:

HEALTH SCIENCES JoURNAL, Vol. 11 No. 02, DESEMBER 2020

DOI: $10.34305 /$ jikbh.v11i2.166
Ciptaan disebarluaskan di bawah

Lisensi Creative Commons

Atribusi-NonKomersial-

BerbagiSerupa 4.0 Internasional.

\section{Metode Pemeriksaan}

Metode flotasi (pengapungan) adalah metode yang menggunakan larutan $\mathrm{NaCl}$ jenuh yang didasarkan atas berat jenis telur sehingga akan mengapung ke permukaan tabung dan ditutup dengan cover gelas sehingga telur cacing naik ke permukaan larutan. Cover gelas tersebut dipindahkan ke objek glass yang bersih dan kering di bawah mikroskop. Dalam metode ini telur cacing tidak langsung dibuat sediaan tetapi sebelum dibuat sediaan sampel diperlakukan sedemikian rupa sehingga telur cacing diharapkan dapat terkumpul. Pengamatan pada pemeriksaan ini diawali dengan pengamatan makroskopik lalu dilanjutkan dengan pengamatan mikroskopik, pengamatan mikroskopik dilakukan pada seluruh lapangan pandang dari sediaan yang dibuat. Hasil pembacaan sediaan telur cacing ini juga hanya dapat dilaporkan secara kualitatif saja, apabila ditemukan telur cacing dilaporkan positif dan sebaliknya apabila tidak ditemukan telur cacing dilaporkan negatif. Ketetapan waktu flotasi merupakan syarat mutlak yang harus dipenuhi sebab didasarkan atas berbagai penelitian, pembacaan sediaan dengan waktu flotasi yang terlalu lama akan menyebabkan telur cacing mengendap kembali sehingga hasil yang terbaca kurang maksimal atau dapat terjadi hasil false (Waqiah, 2010).

\section{Kesimpulan}

Dari hasil penelitian tentang hubungan antara infeksi Soil Transmitted Helminths dan kuku jari tangan maka dapat diambil kesimpulan ditemukan telur nematoda usus STH sebanyak $10 \%$ pada kuku jari tangan dengan metode pengapungan. Jenis telur cacing yang ditemukan adalah Trichuris sp dan Hookworm.

Dilaksanakan penyuluhan atau edukasi tentang bahaya, penularan, pencegahan, dan penanggulangan infestasi Soil Transmitted Helminths melalui penyuluhan di tempat penitipan hewan yang melibatkan semua pihak di dalamnya termasuk kelengkapan APD dan pemberian obat cacing. Serta dilakukan pemeriksaan pada pekerja dengan menggunakan feses untuk mengetahui prevalensi pekerja tempat penitipan hewan yang terinfeksi kecacingan. Selain itu sangat disarankan untuk observasi lebih lanjut tentang penelitian pada tempat penitipan hewan lain di Surabaya secara menyeluruh

\section{Daftar Pustaka}


JURNAL ILMU KESEHATAN BHAKTI HUSADA:

HeAlth SCIENCES JouRnAL, Vol. 11 No. 02, Desember 2020

DOI: $10.34305 /$ jikbh.v11i2.166

(RISKESDAS), D. K. R. I. R. K. D. (2008). No Titl. Badan Penelitian dan Pengembangan Kesehatan.

Akmalia, A. Y., Widyaevan, D. A., \& Anwar, H. (2017). Perancangan Klinik Anjing dan Kucing dengan Pendekatan Programatik. E-Proceeding of Art \& Design, 4(03), 1402.

Aryawan, A. F. G. (2019). Identifikasi Keberadaan Telur Cacing Usus Pada Lalapan sayur Kubur (Brassica oleracea) di Warung Makan Pecer Lele Sepanjang Jalan Kaliurang KM 4,5 - 24 Kota Yogyakarta.

Brawijaya, F. K. H. U. (2012). Manual Prosedur Pelayanan Medis Klinik Hewan.

Chiodini, P. L., Moody, A. H., \& Manser, D. W. (2001). Atlas of Medical Helminthology and protozoology. Elsevier Science Publishing.

Djamilah, M. (2003). Hubungan Sanitasi Lingkungan dan Hygiene Perorangan dengan Kejadian Infeksi Kecacingan pada Anak Usia Sekolah Dasar di Kel. Mangga Dua Kec. Kendari Kota Kendari. Unhas, Makassar.

Dunn, J. J., Columbus, S. T., Aldeen, W. E., Davis, M., \& Carroll, K. C. (2002). Trichuris vulpis recovered from a patient with chronic diarrhea and five dogs. Journal of Clinical Microbiology, 40(7), 2703-2704.

Gandahusada, S., Illahude, H. D., \& Pribadi, W. (2004). Parasitologi Kedokteran. Fakultas Kedokteran UI.

Jejaw, A., Zeynudin, A., Zemene, E., \& Belay, T. (2014). Status of intestinal

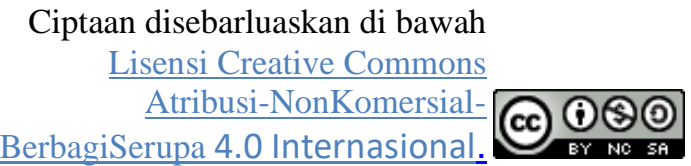

parasitic infections among residents of Jimma Town, Ethiopia. BMC Research Notes, 7(1), 502.

Lamara, O. R. (2013). Hubungan Personal Hygiene Dengan Kandungan Telur Cacing Pada Kotoran Kuku Pekerja Biogas Di Desa Tanjung Harapan Kecamatan Wonosari Kabupaten Boalemo Tahun 2013. Skripsi, 1(811409124).

Notoatmodjo, S. (2010). Ilmu perilaku kesehatan. In Jakarta. Rineka Cipta.

Onggowaluyo, J. S. (2001). Cacing tambang, dalam Parasitologi Medik 1 Helmintologi. In Jakarta. EGC.

Padmasutra, L., Garcia, L. S., Bruckner, D. A., \& Makimian, R. (1996). Diagnostik Parasitologi Kedokteran. EGC.

Pusarawati, S., Ideham, B., Kusmartisnawati, T. I., \& Basuki, S. (2013). Atlas Parasitologi Kedokteran. EGC.

Puspita, L. T. (2013). Pusat Kegiatan bagi Penyayang serta Hewan Anjing dan Kucing di Daerah Istimewa Yogyakarta. Universitas Atma Jaya Yogyakarta.

Rahmadhini, N. S., \& Mutiara, H. (2015). Pemeriksaan Kuku sebagai Pemeriksaan Alternatif dalam Mendiagnosis Kecacingan. Jurnal Majority, 4(9), 113-117.

Setianingsih, I., Arianti, D. C., \& Fadilly, A. (2015). Prevalensi, Agen Penyebab, dan Analisis Faktor Risiko Infeksi Tinea Unguium pada Peternak Babi di Kecamatan Tanah Siang, Provinsi 
Kalimantan Tengah. Jurnal Buski, 5(3), 155-161.

Soedarto Soekirman. (1991). Penuntun Parasitologi Kedokteran. EGC.

Sofiana, L. (2010). Hubungan Perilaku Dengan Infeksi Soil Transmitted Helminths Pada Anak Sekolah Dasar MI Asas Islam Kalibening, Salatiga. Jurnal Kesehatan Masyarakat, 4(2), 76-143.

Subahar, R., Patiah, P., Widiastuti, W., Aulung, A., \& Wibowo, H. (2017). Prevalensi dan Intensitas Infeksi Ascaris Lumbricoides dan Trichuris trichiura Pada Anggota Keluarga Di Jakarta dan Cipanas, Jawa Barat. Jurnal Profesi Medika: Jurnal Kedokteran Dan Kesehatan, 11(1).
Suharsono. (2002). Zoonosis Penyakit menular dari Hewan Ke Manusia. Kanisius.

Surat Keputusan Menteri Kesehatan Nomor: 424/MENKES/SK/VI/2006. (2006). Pedoman Pengendalian Cacingan.

Undang-Undang Republik Indonesia No 2 Tahun 1966. (1996). Hygiene Presiden Republik Indonesia.

Waqiah, U. (2010). Hubungan Hygiene Perorangan dengan Kejadian Infeksi Kecacingan Pada Pemulung Anak Usia Sekolah Dasar di TPA Antang Makassar. Universitas Islam Negeri Alauddin Makassar. 